\title{
Improving Job Quality in Cote d'Ivoire and Burkina-Faso: Role of the Inclusive Business Model $^{*}$
}

\author{
Alban A. E. Ahoure', Kan D. N'Dri' ${ }^{2}$ \\ ${ }^{1}$ University Felix Houphouet Boigny of Cocody, Cote d'Ivoire and CAPEC, Abidjan, Cote d'Ivoire \\ ${ }^{2}$ International University of Grand Bassam, Grand-Bassam, Cote d'Ivoire \\ Email: alban.ahoure@gmail.com,ndrikandavid@gmail.com
}

How to cite this paper: Ahoure, A. A. E., \& N'Dri, K. D. (2020). Improving Job Quality in Cote d'Ivoire and Burkina-Faso: Role of the Inclusive Business Model. Theoretical Economics Letters, 10, 1314-1337. https://doi.org/10.4236/tel.2020.106081

Received: October 16, 2020

Accepted: December 22, 2020

Published: December 25, 2020

Copyright () 2020 by author(s) and Scientific Research Publishing Inc. This work is licensed under the Creative Commons Attribution International License (CC BY 4.0).

http://creativecommons.org/licenses/by/4.0/

(c) (i) Open Access

\begin{abstract}
This study aims to determine the impact of a new business model, called Inclusive Business (IB) model on job quality in two West Africa francophone countries, Burkina-Faso and Cote d'Ivoire, using propensity scores methods and the inverse probability weighted adjusted regression (IPWAR) for robustness. Results show that employees and self-employed related to companies which implement the Inclusive Business (IB) Model have higher labor-related revenues, are less likely to quit their current job and are more satisfied with their labor's income in Burkina-Faso. In Cote d'Ivoire, significant results are only observed for self-employed persons benefiting from this new business model. They earn more and are more satisfied with their working conditions. The IB model which seems to be more matured in Burkina-Faso (returns are observed for both employees and self-employed) than in Cote d'Ivoire, can therefore be viewed as a channel for job quality improvement in these two West African (francophone) countries where it is not yet expanded. Public policies are therefore needed to support the implementation of this new business model.
\end{abstract}

\section{Keywords}

Job Quality, Inclusive Business Model, Propensity Score Matching,

Inverse Probability Weighted Adjusted Regression

\section{Introduction}

Employment since it affects the quality of life in many ways is a crucial element

${ }^{*}$ Data have been collected in a context of a project funded by the International Development Research Center (IDRC), based in Ottawa, Canada. We are grateful to IDRC for her support. 
of well-being (UN, 2015). It is often the key to social and economic progress, providing the individual with a sense of identity and the opportunity to socialize with others. However, it is not without risk. Certain types of employment can have negative effects on employee's health, thus limiting their future working potential.

According to the International Labour Organization (ILO), the main global employment challenge is associated with poor working conditions. For example, the UN has made "decent work for all" one of its priorities in the framework of sustainable development objectives (SDG 8). Having a job does not always guarantee decent living conditions. Evidence of this is the 700 million people living in extreme or moderate poverty, even though they are employed (ILO, 2019). In addition, $61 \%$ of workers worldwide, or 2 billion people, are currently in informal employment. This leads to several challenges, including lack of social protection, extended working hours, the possibility of being dismissed without notice or severance pay, and dangerous working conditions.

In Africa, only $4.5 \%$ of people of working age are unemployed, $36.6 \%$ of the working age population is not in the labour market, and about $60 \%$ of them are employed (ILO, 2019). Rather than being indicators of a well-functioning labour market, these statistics instead hide a much darker reality. Indeed, the majority of working-age Africans generally has poor quality employment which only enables them to meet their basic needs and escape poverty. A significant proportion of the labour force works in conditions characterized by insecurity, low wages and lack of social protection, namely, in activities such as self-employment and family businesses, which together represent about $68 \%$ of the total employment in the region (ILO, 2019). In Cote d'Ivoire, the working population remains poor and mostly employed in vulnerable and precarious jobs. In 2016, virtually $35.5 \%$ of workers were poor, with more farmers (46.7\%) than workers in other sectors (trade (31.4\%), industry (27.0\%) and services $(22.4 \%)$ ). The overall rate of informal employment was estimated at $93.6 \%$ in 2016 (ILO, 2019). Similarly, in Burkina Faso, according to data from the national survey on employment and the informal sector carried out by national institute for statistics in $2015,95.2 \%$ of employed workers are in the informal sector, with $94.1 \%$ of working women in this sector (INSD, 2016).

In view of fighting against poverty and precarious living conditions, African countries have committed themselves to achieve the sustainable development goals (SDGs), including the eradication of poverty in all its forms throughout the world. One way to do this is to support private sector development, which would help creating more jobs and promote inclusive growth. This encourages companies to increasingly include the poor in their value chains. An approach that has given rise to new business models such as the "inclusive business" (IB) model with two complementary objectives: economic performance and significant social impact, through the integration of persons at the bottom of the (social) pyramid (BoPs). 
Adoption of this business model though increasing in East Africa and mainly in Anglophone African countries such as Kenya, is still done at a slow pace in West African francophone countries, which also face the challenge of employment and job quality for an important ratio of their populations. To shed light on how the private sector can contribute to working conditions' improvements in African francophone countries, this paper addresses the issue of the relationship between the Inclusive Business Model and the supply of decent works opportunities, focusing on Burkina-Faso and Cote d'Ivoire.

The study uses a recent survey data gathered through a research project on Economic Inclusion of Youth and Women through the Inclusive Business Model that spanned from June 2017 to October 2019. The survey was conducted using a quasi-experimental protocol between February and May 2019. The econometric analysis involves the propensity score matching (PSM) and the inverse probability weighted adjusted regression (IPWRA) techniques for a purpose of robustness. The remainder of the paper is organized as follows: The next section presents a review of related literature. Section three describes the evaluation method, while section four discusses the empirical results. The conclusion highlights the key findings and policy implications.

\section{Literature Review}

There are several approaches to defining inclusive business or entrepreneurship. A company is inclusive if it is innovative, efficient, and credible, makes products and services accessible and affordable to the poor, creates jobs and has long-term financial and environmental sustainability. Inclusive entrepreneurship improves the social and economic well-being of individuals at the bottom of the pyramid (George \& Khoja, 2012) and preserves local ecosystems by promoting sustainable value creation (Hart \& Milstein, 2003).

Authors such as Comini and Teodosio (2010) consider inclusive entrepreneurship as a subset of social business. It links supply (producers) to demand (consumers), triggering positive processes of economic wealth creation and social empowerment. Other authors define it as a type of organization distinct from social business. Among these authors, Michelini (2012) considers an inclusive enterprise as an organization that builds relationships with the poor, with the aim of integrating them into the value chain. Inclusive economic models are characterized by the integration of the poor in three different ways: 1) the poor people are the main target market for some organizations that create products and provide affordable services; 2) the poor people are involved in a product's value chain, thus contributing to job creation, knowledge sharing and skills transfer, and 3) the poor people are an organization's target market, or are stakeholders involved in the company's value chain. IB differs therefore from corporate social responsibility (CSR), social enterprise, microfinance, and contract farming through a focus on systemic changes for poor people.

However, there is a debate between academics and practitioners on the defini- 
tion of inclusive business. For Liloko and Kini (2017), definitions differ from one group to another depending on whether one is an academic or a development practitioner. Thus, researchers argue that including people at the bottom of the pyramid in the workplace is an approach to poverty reduction (Prahalad \& Ramaswamy, 2004; London \& Hart, 2010). It aims to help the poor meet their basic needs in an economically, socially and environmentally sustainable manner. As such, it is an inclusive development tool that is openly pro-poor. Inclusive enterprises aim to create opportunities, generate sustainable and decent incomes for groups with little or no mobility in the labor market. From the perspective of development practitioners, the use of inclusive entrepreneurship models makes it possible to tap into the labour force of low-income earners and the potential market they represent. For small-scale producers, this type of model strengthens the supply chain of companies. Thus, the inclusive entrepreneurship model is an opportunity for a large number of people, and provides an employment opportunity for the poor (Naguib \& Jamali, 2015).

Inclusive business refers to the inclusion of people living in poverty as producers, consumers, employees or business partners along the value chain. Accordingly, three types of inclusive business models can be distinguished (see Table 1).

Job quality is a concept that can first be defined in terms of the characteristics of each job, based on several dimensions, such as the salary; working conditions, in terms of occupational safety, health, transport, geographical location, autonomy at work, the legal status, the possibility of reconciling work and life outside work. To sum up, a well-paying job, with a stable status and good working conditions, which allows the possibility of a satisfactory life outside work, and in which relations with the working environment are good, is a quality job.

The Laeken European Council of December 2001 endorsed a list of job quality indicators (see Box 1). Some indicators focus on the content of work and working conditions, while others consider the link with the labor market (job security, probability of returning to work in the event of unemployment), or even social protection. Job quality as defined in this way is a multidimensional and more encompassing concept based on more than only working conditions.

Box 1. The dimensions of job quality according to the Laeken indicators.

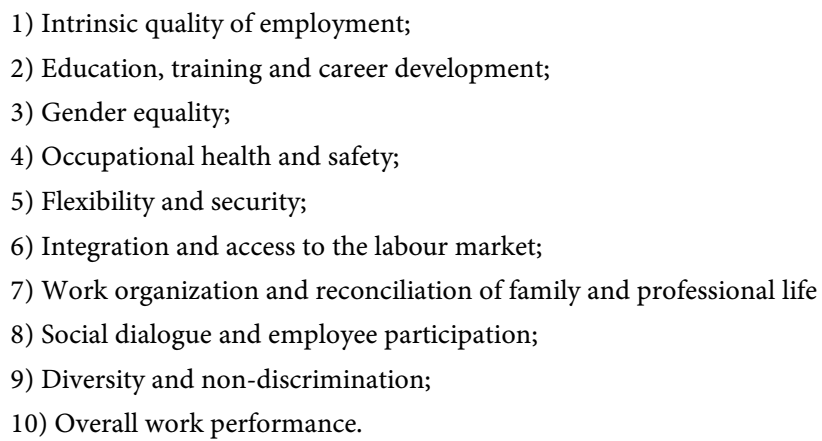

Source: Davoine (2007). 
Table 1. Different types of inclusive business models.

\begin{tabular}{lll}
\hline Poor as & Company Benefits & Poor people Benefit \\
\hline \multirow{2}{*}{ Supplier } & $\bullet$ Strengthening supply chains & $\bullet$ Increasing incomes \\
& $\bullet$ Reducing cost & $\bullet$ Building skills \\
& $\bullet$ Improving the product & $\bullet$ Empowering communities \\
Consumer & $\bullet$ Building new markets & $\bullet$ Improved productivity and quality of life \\
& $\bullet$ Increasing revenues & $\bullet$ Cost saving \\
& $\bullet$ Scaling up and achieving fast growth & $\bullet$ Income opportunities \\
Entrepreneur & $\bullet$ Deepening market penetration and & $\bullet$ Skills \\
& increasing sales & $\bullet$ Empowerment
\end{tabular}

Source: UNDP, 2010.

Apart from traditional economic variables (such as wages and working hours), the quality of a job depends on a wide variety of characteristics (related to its intrinsic value) rarely measured in surveys. Clark (2005), based on an analysis of 19 OECD countries, finds that wages and working hours are considered by workers to be the least important factors in characterizing their employment. On the other hand, factors such as promotion opportunities are more important. Other authors highlight factors such as the type, content of work and interest in or relationship to the workplace (Sousa-Poza \& Sousa-Poza, 2000; D'Addio et al., 2007). Idson (1990) and Garcia-Serrano (2008) emphasize the importance of the work environment.

Beuran and Kalugina (2005) find that in the case of Russia, paradoxically, working in the informal sector increases well-being despite poor working conditions, job insecurity and exclusion from the social benefit system, in addition to significantly lower average incomes. This result is also found in the case of African countries (Razafindrakoto \& Roubaud, 2006), Rakotomanana (2011) shows that in Madagascar, all other things being equal, there is no intrinsic difference in the level of satisfaction between workers in the informal and formal private sectors. However, public sector employees are always more satisfied.

By mobilizing Ghanaian panel data, Falco et al. (2011) also find that the informal and formal sectors (both private and public) provide an equivalent level of satisfaction. That also prevails in Vietnam (Cling et al., 2012). In addition, self-employed persons, who are more autonomous in their activities but face more earnings instability are more satisfied than employees (Blanchflower \& Oswald, 2004); as observed in the case of Ghana by Falco et al. (2011). These results show the importance of factors such as autonomy and independence, flexibility, employment status, quality of labor relations, etc.

Very little focus has been given to study of new businesses' influence on job quality, especially in the economic literature. Considering rather Corporate Social Responsibility (CSR), a close model, Ahmad et al. (2014), using data from three different organizations in Telecom sector of Pakistan, found a weak but significant positive influence on job efficiency, job quality and overall job per- 
formance.

The theoretical grounds for the contribution of inclusive business to job quality can be articulated in the efficiency wage theory (see Clark, 2015). By increasing wages or similarly other aspects of work (job security, working conditions, etc.), firms will induce higher motivation, loyalty, effort, lower propensity to quit and consequently an increased labour productivity, referring to the Gift exchange framework (Akerlof, 1982). By offering opportunities for coaching to BoPs, inclusive firms invest in beneficiaries' human capital (Mincer, 1974; Schultz, 1981), as well as in reducing the mismatch between employer's needs and available competences. Lisi (2018) has demonstrated theoretically that higher matching between investment in education and the task assigned in the workplace, leads to higher job satisfaction. That should reinforce labour productivity and affect positively firms' profitability (Harter et al., 2002). It appears that inclusive firms will invest in improvement of job quality whenever the benefit from such investment outweighs the costs.

Lack of decent employment, along with high unemployment, socio-economic and gender inequalities have contributed to high poverty levels among Africa's youth and women. Inclusive business programs can provide the technical and employable skills, information on jobs, access to capital and better working conditions. In so doing, they will increase support for entrepreneurship and create an enabling environment for good or quality job and contribute to overall individual well-being.

\section{Evaluation Method and Data}

\subsection{Evaluation Strategy}

The impact of inclusive business model on job quality is assessed using the propensity score matching (PSM) and the inverse probability weighted adjusted regression (IPWRA).

\subsubsection{Propensity Score Matching (PSM)}

Matching is one of the most widely used methods to assess the impact of a treatment (Lecocq et al., 2014). The simplest matching method is to compare a treated individual to an untreated one given that both have the same characteristics. To solve this dimensional problem, the vast majority of studies use the propensity score initiated by Rosenbaum and Rubin (1983). The treated group encompasses working persons (employees or self-employed) who are integrated in the value chain of a firm with a clearly defined inclusive business framework. Untreated persons are those of the working populations (employees or self- employed) who are not included in the considered business model.

The participation model is as following:

$$
P\left(T=1 / X_{i}\right)=\beta_{0}+\beta X_{i}+\varepsilon_{i}=p\left(x_{i}, \widehat{\beta}\right)
$$

The variable $T$ (treatment: participating into a clearly defined inclusive busi- 
ness model implemented by a formal (medium or large) firm, as employee or self-employed), is a dichotomous variable. $X$ is a matrix of the observed covariates (sector of activity, being a member of a professional association (including union), education (have ever been to school or never, enterprise is formally registered or not, having received a technical training, sex, age, tenure, country's dummy). This treatment probability is estimated through a Logit or Probit framework, with $p\left(x_{i}\right)$ is the estimated propensity score for individual $i$.

Whence individuals are matched, PSM assumes that there are no systematic differences in unobservable characteristics between treated and untreated individuals. Given this assumption of conditional independence and the overlap conditions, average treatment effect for the treated (those who benefited from the IB model), ATT, is computed as:

$$
\mathrm{ATT}=E\left[\left(\text { JobQuality }_{\text {benef }}-\text { JobQuality }_{\text {NonBenef }}\right) / X\right]=1
$$

Considering barriers (lack of clear public incentives for adoption of this business model and weakness of firms' knowledge on returns to it), the effect of this business model on all workers or self-employed (Average Treatment Effect or ATE) may be unrealistic. Our goal is to document on its effect on current beneficiaries.

The propensity score matching method is based on two assumptions: the conditional independence hypothesis (treatment is assumed to be as good as randomly assigned after conditioning on covariates (Fougère, 2007)) and the common support hypothesis. The conditional independence hypothesis requires having enough observable characteristics so that being treated or not does not depend on the expected outcome (Givord, 2015). The common factor of the propensity score is determined to ensure that for each beneficiary of the inclusive business framework, there is a non-beneficiary one with the same propensity score.

\subsubsection{The Inverse Probability Weighted Adjusted Regression (IPWRA)}

The propensity score model could be based on a large number of spurious specifications and thus gives rise to an embedded bias, as argued by Robins et al. (2007) and Wooldridge (2007). In such cases, the use of the IPWRA estimate would correct the bias. Following Imbens and Wooldridge (2009), ATT in IPWRA estimation is executed in two steps.

More specifically, assume that the outcome variable can be modeled as a linear regression of the form with the treatment taking value 0 ( $t=0$ for untreated) or $1(t=1$ for treated $))$ :

$$
\text { JobQuality }_{t}=\alpha_{t}+X \phi_{t}+\varepsilon_{t}, \quad t \in[0 ; 1]
$$

In this procedure, the quasi-log likelihood is weighted by the inverse of the propensity scores.

The first step consists of estimating the scores and in the second step, $\left(\alpha_{0}, \beta_{0}\right)$ and $\left(\alpha_{1}, \beta_{1}\right)$ are estimated from a weighted least squares method as 
follows (considering JobQuality ${ }_{i}=Y_{i}$ ):

$$
\begin{aligned}
& \underbrace{\min }_{\alpha_{0}, \phi_{0}}=\sum_{i}^{N}\left(Y-\alpha_{0}-X \phi_{0}\right) / p\left(x_{i}\right) \text { if } T_{i}=0 \\
& \underbrace{\min }_{\alpha_{1}, \phi_{1}}=\sum_{i}^{N}\left(Y_{i}-\alpha_{1}-X \phi_{1}\right) / p\left(x_{i}\right) \text { if } T_{i}=1 \\
& \text { ATT }=\frac{1}{N_{T}} \sum_{i}^{N_{T}}\left[\left(\widehat{\alpha}_{1}-\widehat{\alpha}_{0}\right)-\left(\hat{\phi}_{1}-\widehat{\phi}_{0}\right) X_{i}\right]
\end{aligned}
$$

Where, are the estimated inverse probability weighted parameters for the treated individuals, whereas $\left(\widehat{\alpha}_{0}, \widehat{\beta}_{0}\right)$ corresponds to the estimated inverse probability weighted parameters for the non-treated. $N_{T}$ is the total number of treated individuals (Wossen et al., 2017) ${ }^{1}$, which in this case is the total number of BoPs who got integrated in inclusive business program.

\subsection{Data}

The data used in this study are gathered through a survey conducted between February and May 2019 in Burkina Faso and Cote d'Ivoire using a quasi-experimental protocol, as part of a research project on Economic Inclusion of Youth and Women through the Inclusive Business Model. It covered a sample of 576 beneficiaries of an IB model and 1047 counterfactuals in Cote d'Ivoire and a sample of 302 beneficiaries and 790 non-beneficiaries in Burkina Faso. A two-stage survey was used to select the treated and control groups.

The selection of the treated group was made from the BoPs' lists obtained from companies (surveyed at a first stage of the data collection process) that declared implementing a clear IB model and interacting with several BoPs in their value chain. A BoP is defined as a person living under the poverty line in the considered country or a vulnerable person (women/youth in rural areas, persons with disabilities, etc.). The control groups were identified from a household or small business enumeration in the areas where the beneficiary BoPs were located.

For each beneficiary surveyed, two non-beneficiaries with the same profile (area of activity, sector of activity, age group, sex, disability situation) were selected for the survey of non-beneficiaries. In each stratum, the number of non-beneficiaries to be surveyed is at least equal to the double of the beneficiaries. The choice of beneficiaries has been made randomly within each group of age, sex and disability. That of non-beneficiaries has also been made randomly among the non-beneficiaries identified in accordance with the profile of the beneficiaries. Main variables are described in Table 2.

\section{Results}

\subsection{Descriptive Statistics}

Table 3 shows the income level according to whether or not the employee be${ }^{1}$ The development draws from the synthesis done by Wossen et al. (2017). 
longs to an inclusive business program. It reveals that on average, beneficiaries (236.81 USD on average with a standard deviation of 878.57 USD)) of such a program has higher monthly income than non-beneficiaries (146.01 USD in average with a standard deviation of 297.30 USD). The proportion of individuals seeking a new job is higher than that of individuals not seeking in both beneficiaries and non-beneficiaries groups in Burkina-Faso.

It appears that a higher proportion of employees are satisfied with their income in Burkina Faso, whether or not they are beneficiaries of an IB program. In addition, employees who benefit from IB are less satisfied than those who do not. In Cote d'Ivoire, the pattern is different; most of individuals interviewed were not satisfied with their income. However, the proportion of individuals satisfied with their income is higher among beneficiaries of IB.

With regards to working conditions, the analysis of the employees' perceptions indicates that benefiting from an inclusive business program leads to greater satisfaction with working conditions. Table 4 shows that a company in an inclusive entrepreneurship program could promote access to social protection for these employees. According to the data, about $51.33 \%$ of employees benefiting from inclusive business programs have access to social protection; unlike employees of non-recipient companies with a proportion of (69.53\%) without social protection.

Table 2. Variables description.

\begin{tabular}{lll}
\hline Treatment variable & Access or not to an inclusive entrepreneurship initiative & \\
\hline & Age of the employee or self-employed & Continuous \\
& Employee's gender & Discrete $(1=$ Woman, $2=$ Man $)$ \\
Instruction & Discrete $(1=$ Yes, $2=$ No $)$ \\
Matching variables & Employee's marital status, & Discrete $(1=$ Common-law partnership, $2=$ Single, $3=$ Married, \\
& Sector of activity & Discrete $(1=$ Agriculture, $2=$ Other sector $)$ \\
& Professional training & Discrete $(1=$ Yes, $2=$ No $)$ \\
& Have a tax declaration of existence & Discrete $(1=$ Yes, $2=$ No $)$ \\
& Member of an association & Discrete $(1=$ Yes, $2=$ No $)$ \\
\hline \multirow{3}{*}{ Job quality variables } & Log of monthly income & Continuous \\
& Satisfaction with income & Discrete $(1=$ Yes, $2=$ No $)$ \\
& Satisfaction with their working conditions & Discrete $(1=$ Yes, $2=$ No $)$ \\
& Social protection & Discrete $(1=$ Yes, $2=$ No $)$ \\
\hline
\end{tabular}

Source: Author.

Table 3. Income level according to whether or not the employee belongs to an inclusive business program.

\begin{tabular}{ccccc}
\hline & Mean & Standard deviation & Minimum & Maximum \\
\hline Beneficiary employees & 236.81 & 878.57 & 14.44 & $14,440.43$ \\
Non-beneficiary employees & 146.01 & 297.30 & 18.05 & 5054.15 \\
\hline
\end{tabular}

Source: Author based on survey data. Notes: The figures are in US dollars. 
Table 4. Inclusive business and some dimensions of job quality (job quit, satisfaction with income, satisfaction with working conditions and access to social protection) for employees.

\begin{tabular}{|c|c|c|c|c|c|c|}
\hline & \multicolumn{2}{|c|}{ All (\%) } & \multicolumn{2}{|c|}{ Burkina Faso (\%) } & \multicolumn{2}{|c|}{ Cote d'Ivoire (\%) } \\
\hline & NonBenef & Benef. & NonBenef & Benef. & NonBenef & Benef. \\
\hline \multirow{2}{*}{\multicolumn{7}{|c|}{$\begin{array}{l}\text { Have you (recently) } \\
\text { looked for another job? }\end{array}$}} \\
\hline & & & & & & \\
\hline No & 30.31 & 42.00 & 21.26 & 42.42 & 45.58 & 41.48 \\
\hline Yes & 69.69 & 58.00 & 78.74 & 57.58 & 54.42 & 58.52 \\
\hline \multicolumn{7}{|c|}{$\begin{array}{l}\text { Are you satisfied with your } \\
\text { income? }\end{array}$} \\
\hline Satisfied & 54.26 & 52.33 & 60.9 & 58.2 & 43.05 & 45.19 \\
\hline Not satisfied & 45.74 & 47.67 & 39.1 & 41.8 & 56.95 & 54.81 \\
\hline \multicolumn{7}{|c|}{$\begin{array}{l}\text { Are you satisfied with } \\
\text { your working conditions? }\end{array}$} \\
\hline Satisfied & 65 & 71.57 & 66.52 & 81.10 & 59.11 & 60 \\
\hline Not satisfied & 35 & 28.43 & 31.48 & 18.9 & 40.89 & 40 \\
\hline \multicolumn{7}{|c|}{$\begin{array}{c}\text { Do you have social } \\
\text { protection? }\end{array}$} \\
\hline No & 69.53 & 30.47 & 87.5 & 71.43 & 96.4 & 91.11 \\
\hline Yes & 48.67 & 51.33 & 12.5 & 28.57 & 3.6 & 8.89 \\
\hline
\end{tabular}

Source: Authors based on survey data.

For that concerns the self-employed people, the average levels for labor-related incomes and working hours and the proportions for those who have looked for another job, are satisfied with their income, are satisfied with their working conditions or have a social protection are presented in appendices for beneficiaries and non-beneficiaries along with the results of the differences tests. Table A2 (in Appendix) bears on the full data set. Separate results for each country, Burkina-Faso and Cote d'Ivoire, are presented respectively in Table A3 and Table A4. Considering the full data, we note that the average earnings of the beneficiaries are significantly higher. Their weekly working hours are in average lower and higher proportions of this group (the treated) are satisfied with their income and also with their working conditions. A higher proportion of beneficiaries, compared with non-beneficiaries, has access to a social protection and a weaker proportion is looking for another job. Based on these statistics, we can assess that the IB model should improve the job quality's level of self-employed people. The estimation of the impact will help confirming or not these preliminary results.

\subsection{Impact Assessment}

\subsubsection{Determinants of Working in or Being in a Business Relationship (for Self-EMPLOYED) with an Inclusive Firm}

The logistic regression for employees (Table 5) shows that the probability of an 
employee being in an inclusive business initiative depends on the employee's age, whether or not they received a technical training, the possession of a tax registration certificate by the firm, marital status and the country of operation.

Table 5. Determinants to work in an inclusive business firm, for employees.

\begin{tabular}{|c|c|c|c|c|c|c|}
\hline \multirow{2}{*}{$\begin{array}{l}\text { Working in an } \\
\text { inclusive firm }\end{array}$} & (1) & (2) & (3) & (4) & (5) & (6) \\
\hline & Total & $\begin{array}{l}\text { odds } \\
\text { ratio }\end{array}$ & $\begin{array}{l}\text { Cote } \\
\text { d'Ivoire }\end{array}$ & $\begin{array}{l}\text { odds } \\
\text { ratio }\end{array}$ & $\begin{array}{l}\text { Burkina } \\
\text { Faso }\end{array}$ & $\begin{array}{l}\text { odds } \\
\text { ratio }\end{array}$ \\
\hline \multicolumn{7}{|l|}{$\begin{array}{l}\text { Sector of activity } \\
\text { (ref: agriculture) }\end{array}$} \\
\hline \multirow[t]{2}{*}{ Manufacturing } & $-0.658^{* * *}$ & $0.518^{\star * *}$ & $-0.963^{\star * \star}$ & $0.382^{* * *}$ & $-0.564^{\star}$ & $0.569^{\star}$ \\
\hline & $(0.225)$ & $(0.117)$ & $(0.267)$ & $(0.102)$ & $(0.292)$ & $(0.166)$ \\
\hline \multirow[t]{2}{*}{ Service/Trade } & $-0.363^{*}$ & $0.695^{\star}$ & $-0.950^{* *}$ & $0.387^{\star *}$ & $-1.029^{* * *}$ & $0.357^{* * *}$ \\
\hline & $(0.195)$ & $(0.136)$ & $(0.420)$ & $(0.162)$ & $(0.249)$ & $(0.089)$ \\
\hline \multirow{3}{*}{$\begin{array}{c}\text { Member of a } \\
\text { professional association } \\
(\text { Yes }=1, \text { No }=0)\end{array}$} & & & & & & \\
\hline & $0.318^{\star}$ & $1.374^{\star}$ & 0.395 & 1.485 & 0.311 & 1.365 \\
\hline & $(0.168)$ & $(0.231)$ & $(0.250)$ & $(0.371)$ & $(0.245)$ & $(0.334)$ \\
\hline \multirow[t]{2}{*}{$\begin{array}{c}\text { Instruction } \\
(\mathrm{Yes}=1, \mathrm{No}=0)\end{array}$} & $0.331^{\star}$ & $1.392^{\star}$ & 0.282 & 1.326 & 0.353 & 1.423 \\
\hline & $(0.193)$ & $(0.269)$ & $(0.293)$ & $(0.389)$ & $(0.264)$ & $(0.376)$ \\
\hline \multirow[t]{2}{*}{$\begin{array}{l}\text { Your enterprise has a } \\
\text { DFE }(\text { Yes }=1, \text { No }=0)\end{array}$} & $1.235^{\star * \star}$ & $3.439^{* * *}$ & $1.101^{* * *}$ & $3.008^{* * *}$ & $1.406^{* * *}$ & $4.082^{* * *}$ \\
\hline & $(0.191)$ & $(0.657)$ & $(0.413)$ & $(1.24)$ & $(0.228)$ & $(0.931)$ \\
\hline \multirow[t]{2}{*}{$\begin{array}{l}\text { Technical training } \\
(\text { Yes }=1, \text { No }=0)\end{array}$} & $0.715^{\star * \star}$ & $2.044^{* * *}$ & 0.383 & 1.467 & $0.971^{\star * *}$ & $2.640^{* * *}$ \\
\hline & $(0.229)$ & $(0.469)$ & $(0.491)$ & $(0.720)$ & $(0.265)$ & $(0.699)$ \\
\hline \multirow{2}{*}{$\begin{array}{c}\text { Marital status } \\
(\text { Married }=1, \\
\text { Not married }=0)\end{array}$} & $0.315^{\star}$ & $1.370^{*}$ & 0.432 & 1.540 & 0.039 & 1.040 \\
\hline & $(0.171)$ & $(0.235)$ & $(0.288)$ & $(0.443)$ & $(0.225)$ & $(0.234)$ \\
\hline \multirow[t]{2}{*}{$\begin{array}{c}\text { Gender }(\text { Male }=1, \\
\text { Female }=0)\end{array}$} & -0.045 & 0.956 & 0.054 & 1.056 & -0.106 & 0.900 \\
\hline & $(0.173)$ & $(0.165)$ & $(0.300)$ & $(0.317)$ & $(0.215)$ & $(0.194)$ \\
\hline \multirow[t]{2}{*}{ Age } & $0.023^{* *}$ & $1.023^{* *}$ & $0.032^{* *}$ & $1.033^{* *}$ & 0.017 & 1.017 \\
\hline & $(0.009)$ & $(0.010)$ & $(0.016)$ & $(0.017)$ & $(0.013)$ & $(0.013)$ \\
\hline \multirow[t]{2}{*}{ Tenure } & 0.013 & 1.013 & 0.025 & 1.025 & 0.006 & 1.006 \\
\hline & $(0.014)$ & $(0.014)$ & $(0.021)$ & $(0.022)$ & $(0.023)$ & $(0.022)$ \\
\hline \multirow[t]{2}{*}{$\begin{array}{c}\text { Country } \\
(\mathrm{CIV}=0, \mathrm{BF}=1)\end{array}$} & $-0.822^{\star * *}$ & $0.439^{* * *}$ & & & & \\
\hline & $(0.193)$ & $(0.084)$ & & & & \\
\hline \multirow[t]{2}{*}{ Constant } & $-1.616^{\star * *}$ & $0.199^{\star * *}$ & $-2.053^{* * *}$ & $0.128^{\star * *}$ & $-1.816^{\star * *}$ & $0.163^{\star * *}$ \\
\hline & $(0.394)$ & $(0.078)$ & $(0.594)$ & $(0.076)$ & $(0.446)$ & $(0.073)$ \\
\hline Observations & 919 & 919 & 361 & 361 & 558 & 558 \\
\hline
\end{tabular}

DFE: Déclaration Fiscale d'Existence. Tax Registration Certificate, Robust standard errors in parentheses; ${ }^{* * *} p<0.01,{ }^{* *} p<0.05,{ }^{*} p<0.1$. 
Indeed, the propensity for an employee working in a formal business to benefit from an IB model is higher than that of an employee in the informal sector. Likewise, the agricultural sector offers more chances to an employee of being in an IB initiative than any other sector. Also, the likelihood to benefit from an IB initiative is higher when the employee is a member of an association.

Having received a technical training increases an employee's probability of being integrated with an IB model. Married employees also have a higher propensity to be beneficiaries. However, the probability for an employee living in Burkina Faso to be in an inclusive business program is lower than that of those living in Cote d'Ivoire, ceteris paribus.

The results obtained by considering each country specifically show that the likelihood of an employee living in Cote d'Ivoire to be a beneficiary of an inclusive business program is determined by the legal status of the company (having a tax registration certificate (DFE)), the area of business (belonging to the agricultural sector) and the employee's age. For those in Burkina Faso, the probability of being a beneficiary depends also on the area of business (agricultural activity), the legal status of the enterprise and having received a technical training.

To ensure that for each beneficiary employee, we can find at least one nonbeneficiary employee who has at least the same characteristics, the common support region of propensity scores is constructed; ranges [0.0899, 0.9009] for the full dataset, $[0.0757,0.8924]$ for Burkina Faso and $[0.1032,0.9232]$ for Cote d'Ivoire. Figure 1, Figure 2 illustrate the histogram of the propensity score for each group, thus visualizing their degree of juxtaposition and the common support area. The Distribution of the number of employees matched by blocks is presented in Table A1 in Appendix.

Determinants for a self-employed people to operate their activities in an IB environment (benefiting from a clear IB program implemented by a larger firm) are presented in Table A5 in Appendix. Operating in the agricultural sector, belonging to a professional association and having a formal (versus informal) activity, are significant variables affecting the probability to be a beneficiary of the IB model.

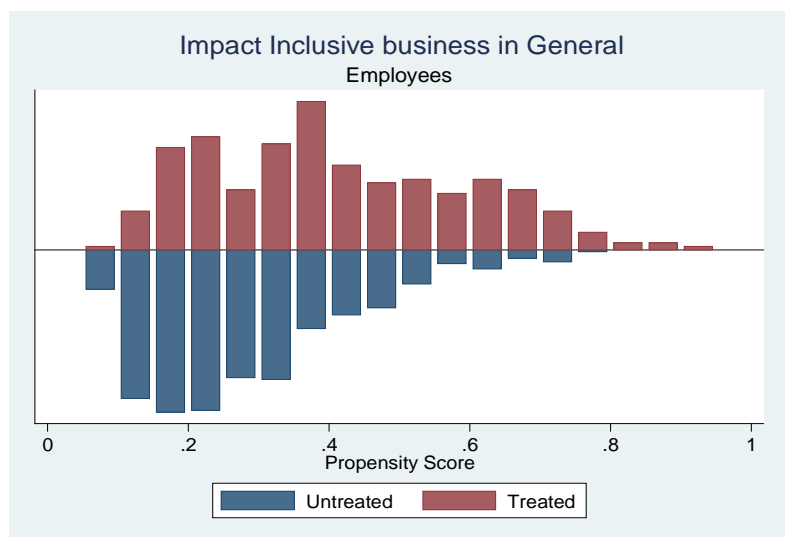




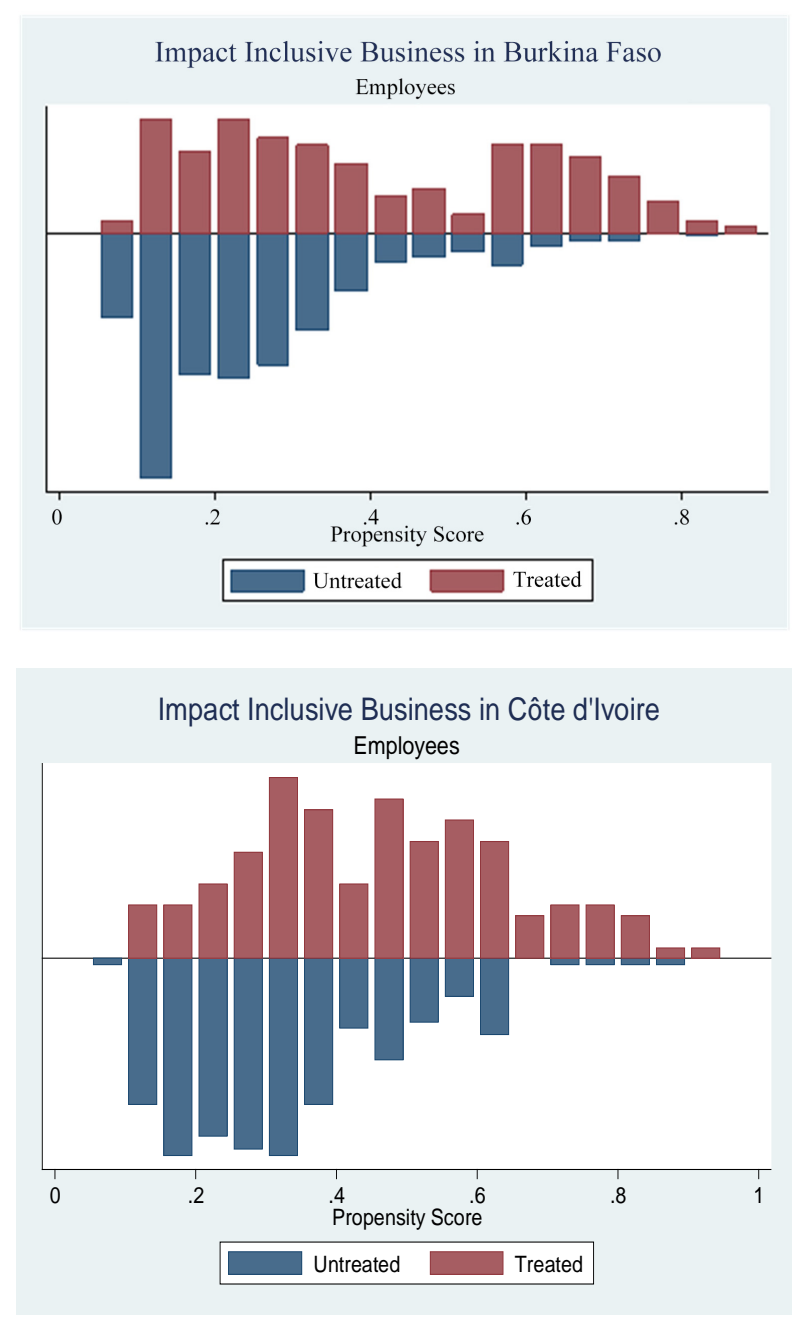

Figure 1. Common support region for beneficiary and non-beneficiary employees for the full dataset, Burkina Faso and Côte d'Ivoire. Source: Author's computation.

\subsubsection{Average Impact of the Inclusive Business Model on Job Quality}

The estimated average treatment effect (ATE) shows that there is no difference between the means of the propensity scores of the two groups of individuals. The test of the equilibrium property of propensity scores reveals that this property is satisfied. The table shows the lower bound, the number of treaties and the number of individuals in the control group of each block.

This step consists in testing within each block that the averages of each characteristic do not differ between the treated employees and the employees in the control group. With the balance test verified (see Appendix), the impact of IB on job quality indicators can be estimated by matching methods.

The first two columns of Table 6 present the treatment effects of benefiting from an IB model using two estimators of PSM (nearest neighbor method and stratification); the third column presents the results of the inverse probability weighted adjusted regression (IPWRA). In general, the impact results are robust for all estimation strategies. 
Table 6. Average treatment effect on job quality (total sample of employees).

\begin{tabular}{cccc}
\hline VARIABLES & $\begin{array}{c}\text { PSM } \\
\text { (nearest neighboring) }\end{array}$ & $\begin{array}{c}\text { PSM } \\
\text { (stratification method) }\end{array}$ & IPWRA \\
\hline Log monthly income & $0.329^{* * *}$ & $0.225^{* * *}$ & $0.172^{*}$ \\
& $(0.136)$ & $(0.093)$ & $(0.101)$ \\
Looking for a new job & $-0.172^{* * *}$ & $-0.143^{* * *}$ & $-0.118^{* *}$ \\
& $(0.073)$ & $(0.053)$ & $(0.054)$ \\
Satisfaction with income & $0.213^{* * *}$ & $0.121^{* * *}$ & $0.116^{* *}$ \\
Satisfaction with & $(0.074)$ & $(0.052)$ & $(0.054)$ \\
working conditions & -0.110 & -0.026 & -0.041 \\
Access to social & $(0.069)$ & $(0.050)$ & $(0.049)$ \\
protection & 0.086 & 0.072 & 0.075 \\
Observations & $(0.055)$ & $(0.043)$ & $(0.046)$ \\
Beneficiaries & 497 & 909 & 919 \\
Non Beneficiaries & 299 & 294 & 299 \\
\hline
\end{tabular}

Source: CAPEC from the beneficiary survey, CAPEC-IDRC 2019, ${ }^{* * *} p<0.01,{ }^{* *} p<0.05,{ }^{*} p<0.1$.

The results of the average treatment effect on job quality show that estimated coefficients of three (3) out of the five (5) indicators of job quality are significant. These are the employee's monthly income, will to quit or looking for a new job and satisfaction with income.

Indeed, regardless of the estimation method, benefiting from an IB initiative has contributed to the improvement of beneficiaries' labor income, with a gain of $33 \%$ (significant at a $1 \%$ level) by the nearest neighbor method, $22 \%$ (1\% level of significance) by the stratification method and $17 \%$ by the IPWRA (significant at $10 \%$ level). Beneficiaries are also less likely to seek new employment showing a lower propensity to quit the current employer. The likelihood to quit for beneficiaries is $12 \%$ (IPWRA) to $17 \%$ lower (nearest neighbor or NN). It comes out also that employees in an IB program are more satisfied with their labor's income. The average treatment effect is between 12\% (stratification method and IPWRA) and 21\% (nearest neighbor).

Focusing on the specific case of Burkina-Faso, results show that being integrated in the value chain of an inclusive enterprise has a significant positive impact on income (a proxy of labor's productivity), on job retention (low propensity to quit) and on satisfaction with income (Table 7).

However, considering the case of Cote d'Ivoire (Table 8), it appears that IB model does not have a significant impact on any of the selected job quality indicators. There is no significant difference between employees-beneficiaries of an inclusive business initiative or working in an IB firm and their counterparts (no beneficiaries), concerning the selected indicators of job quality. 
Table 7. Average treatment effect on job quality for employees in Burkina Faso.

\begin{tabular}{cccc}
\hline VARIABLES & $\begin{array}{c}\text { PSM (nearest } \\
\text { neighboring) }\end{array}$ & $\begin{array}{c}\text { PSM (stratification } \\
\text { method) }\end{array}$ & IPWRA \\
\hline Log monthly income & $0.220^{* *}$ & $0.217^{* * *}$ & $0.209^{* * *}$ \\
& $(0.151)$ & $(0.099)$ & $(0.074)$ \\
Looking for a new job & $-0.226^{* * *}$ & $-0.178^{* * *}$ & $-0.150^{* * *}$ \\
& $(0.095)$ & $(0.071)$ & $(0.047)$ \\
Satisfaction with income & $0.145^{* * *}$ & $0.175^{* * *}$ & $0.106^{* *}$ \\
& $(0.097)$ & $(0.071)$ & $(0.047)$ \\
Satisfaction with & -0.042 & -0.016 & -0.005 \\
working conditions & $(0.086)$ & $(0.063)$ & $(0.056)$ \\
Social protection & 0.099 & 0.123 & 0.066 \\
Observations & $(0.085)$ & $(0.068)$ & $(0.047)$ \\
Beneficiaries & 275 & 454 & 558 \\
Non Beneficiaries & 164 & 164 & 164 \\
\hline
\end{tabular}

Source: Author'S computation from the EMBEM database (2015), ${ }^{* *} p<0.01 ;{ }^{* *} p<0.05 ;{ }^{*} p<0.1$.

Table 8. Average treatment effect on job quality for employees in Cote d'Ivoire

\begin{tabular}{cccc}
\hline VARIABLES & $\begin{array}{c}\text { PSM (nearest } \\
\text { neighboring) }\end{array}$ & $\begin{array}{c}\text { PSM (stratification } \\
\text { method) }\end{array}$ & IPWRA \\
Log monthly income & -0.165 & -0.063 & 0.071 \\
Looking for a new job & $(0.280)$ & $(0.199)$ & $(0.107)$ \\
& -0.014 & -0.001 & 0.040 \\
Satisfaction with income & $(0.117)$ & $(0.090)$ & $0.061)$ \\
Satisfaction with & 0.012 & 0.032 & $(0.048)$ \\
working conditions & $(0.116)$ & $(0.099)$ & 0.018 \\
& 0.049 & 0.021 & $(0.056)$ \\
Social protection & $(0.118)$ & $(0.097)$ & 0.042 \\
Observations & 0.035 & 0.014 & $(0.305)$ \\
Beneficiaries & $(0.059)$ & $(0.049)$ & 361 \\
Non-beneficiaries & 214 & 359 & 135 \\
\hline
\end{tabular}

Source: author's computation from the EMBEM database (2015), ${ }^{* * *} p<0.01 ;{ }^{* *} p<0.05 ;{ }^{*} p<0.1$.

\subsection{Impact Assessment on Self-Employed}

After having analyzed the impact on the quality of employment of employees, we are interested by how this business model does affect self-employed people in terms of income related to their activity, propensity to change activity, satisfaction with income or working conditions and access to social protection. Results for the full data, specifically for Burkina-Faso and for Cote d'Ivoire are presented respectively in Tables 9-11. 
Table 9. Average treatment effect on job quality of self-employed (total).

\begin{tabular}{cccc}
\hline VARIABLES & PSM & PSM & IPWRA \\
& (Nearest neighboring) & (Stratification method) & \\
\hline Log monthly income & $0.511^{* * *}$ & $0.554^{* * *}$ & $0.690^{* * *}$ \\
Looking for a new & $(0.095)$ & $(0.073)$ & $(0.086)$ \\
professional activity & -0.024 & -0.066 & $-0.063^{*}$ \\
$\begin{array}{c}\text { Satisfaction with income } \\
\text { Satisfaction with }\end{array}$ & $0.106^{* *}$ & $(0.044)$ & $(0.034)$ \\
working conditions & $(0.052)$ & $0.129^{* * *}$ & $0.115^{* * *}$ \\
& $0.120^{* *}$ & $(0.129)$ & $(0.037)$ \\
Social protection & $(0.050)$ & $0.131^{* * *}$ & $0.117^{* * *}$ \\
Observations & $0.032^{* *}$ & $(0.029)$ & $(0.034)$ \\
Beneficiaries & $(0.014)$ & $0.031^{* *}$ & 0.013 \\
Non Beneficiaries & 724 & $(0.014)$ & $(0.019)$ \\
\hline
\end{tabular}

Source: author's computation from the EMBEM database (2015), ${ }^{\star * *} p<0.01$; ${ }^{* \star} p<0.05 ;{ }^{\star} p<0.1$.

Table 10. Average treatment effect on job quality for self-employed in Burkina Faso.

\begin{tabular}{|c|c|c|c|}
\hline VARIABLES & $\begin{array}{c}\text { PSM } \\
\text { (Nearest neighboring) }\end{array}$ & $\begin{array}{c}\text { PSM } \\
\text { (Stratification method) }\end{array}$ & IPWRA \\
\hline \multirow[b]{2}{*}{ Log monthly income } & $0.485^{\star * *}$ & $0.544^{* * *}$ & $0.523^{\star * *}$ \\
\hline & $(0.108)$ & $(0.107)$ & $(0.106)$ \\
\hline \multirow{2}{*}{$\begin{array}{l}\text { Looking for a new } \\
\text { professional activity }\end{array}$} & $-0.180^{\star *}$ & $-0.178^{\star * *}$ & $-0.124^{\star *}$ \\
\hline & $(0.073)$ & $(0.054)$ & $(0.062)$ \\
\hline \multirow{2}{*}{ Satisfaction with income } & $0.200^{\star * *}$ & $0.217^{\star * *}$ & $0.197^{\star * *}$ \\
\hline & $(0.066)$ & $(0.052)$ & $(0.055)$ \\
\hline Satisfaction with & 0.048 & 0.099 & $0.092^{*}$ \\
\hline working conditions & $(0.066)$ & $(0.059)$ & $(0.052)$ \\
\hline \multirow[b]{2}{*}{ Social protection } & $0.096^{*}$ & $0.084^{* *}$ & $0.079^{*}$ \\
\hline & $(0.053)$ & $(0.041)$ & $(0.046)$ \\
\hline Observations & 213 & 385 & 371 \\
\hline Beneficiaries & 109 & 109 & 109 \\
\hline Non Beneficiaries & 104 & 276 & 262 \\
\hline
\end{tabular}

Source: author's computation from the EMBEM database (2015), ${ }^{* *} p<0.01 ;{ }^{* *} p<0.05{ }^{*} p<0.1$. 
Table 11. Average treatment effect on job quality for self-employed in Cote d'Ivoire.

\begin{tabular}{cccc}
\hline VARIABLES & PSM & PSM & IPWRA \\
\hline Log monthly income & $0.476^{* * *}$ & $0.560^{* * *}$ & $0.531^{* * *}$ \\
& $(0.131)$ & $(0.132)$ & $(0.087)$ \\
Looking for a new & -0.007 & -0.025 & 0.008 \\
professional activity & $(0.065)$ & $(0.040)$ & $(0.037)$ \\
Satisfaction with income & 0.095 & 0.062 & 0.046 \\
& $(0.066)$ & $(0.050)$ & $(0.038)$ \\
Satisfaction with & $0.131^{* *}$ & $0.135^{* * *}$ & $0.166^{* * *}$ \\
working conditions & $(0.065)$ & $(0.036)$ & $(0.039)$ \\
Social protection & 0.004 & 0.004 & -0.001 \\
Observations & $(0.012)$ & $(0.011)$ & $(0.012)$ \\
Beneficiaries & 512 & 761 & 742 \\
Non Beneficiaries & 282 & 282 & 282 \\
\hline
\end{tabular}

Source: Author'S computation from the EMBEM database (2015), ${ }^{* * *} p<0.01$; $^{* *} p<0.05$; $^{\star} p<0.1$.

Overall, the results reveal that inclusive business initiatives have a positive significant impact on income related to the professional activities of self- employed. Similarly, beneficiaries are more satisfied with their income and working conditions than non-beneficiaries (Table 9). These results are significant at $1 \%$ or $5 \%$ for the three methods (PSM nearest neighboring, PSM stratification method and IPWRA). In Burkina-Faso (Table 10), impact is significant for earnings ( $+49 \%$ to $56 \%$ for beneficiaries), propensity to quit (reduction of the probability to look for a new job between $12 \%$ and $18 \%$ ), satisfaction with income (higher probability of $20 \%-22 \%$ for beneficiaries) and access to social protection (8.4\% at a significance level of 5\% for PSM stratification method). It appears that in Cote d'Ivoire, self-employed persons who benefit from an inclusive business initiative earn around 50\% more and their probability to be satisfied with their working conditions is $13 \%$ to $17 \%$ higher, compared to non- beneficiaries (Table 11).

\section{Conclusion}

Job quality is central to public debates in Africa in the context of recurrent discussions on policies to reduce unemployment. In addition, the size of the informal sector calls for attention to the issue of job quality. The objective of this study was to assess the impact of the inclusive business model on job quality. Based on new microdata collected in Burkina-Faso and Cote d'Ivoire in the context of a research project, results show that employees working in an inclusive firm with a defined program for BoPs have higher labor incomes, are less likely 
to quit and are more satisfied with their income than their counterparts in non-inclusive company. These results are confirmed in Burkina-Faso both for employees and self-employed persons. For that concerns Cote d'Ivoire, being integrated in the value chain of an inclusive firm has rather positive and significant impact on earnings and satisfaction with working conditions for self- employed persons. This business model seems therefore more mature in Burkina-Faso than in Cote d'Ivoire.

Though, little experimented in these two (2) West Africa francophone countries, the inclusive business model can be seen as a channel through which private enterprises can contribute to improvement of job quality. Public policies are needed to support diffusion and implementation of this new business model in these two countries. The study uses cross-sectional data, which can be a limitation since the impact of inclusive business is observed in the short run. In terms of research perspective, a long term analysis could be carried out. It would consist of collecting data on the same cohort of individuals one or two years later.

\section{Conflicts of Interest}

The authors declare no conflicts of interest regarding the publication of this paper.

\section{References}

Ahmad, I., Shehzad, K., \& Zafar, A. M. (2014). Impact of CSR Perception on Dimensions of Job Performance with Mediating Effect of Overall Justice Perception. European Journal of Business and Management, 6, 94-108.

Akerlof, G. A. (1982). Labor Contracts as Partial Gift Exchange. The Quarterly Journal of Economics, 97, 543-569. https://doi.org/10.2307/1885099

Beuran, M., \& Kalugina, E. (2005). Subjective Welfare and the Informal Sector: The Case of Russia. Documento de trabajo. ROSES París I, TEAM CNRS, París.

Blanchflower, D. G., \& Oswald, A. J. (2004). Well-Being over Time in Britain and the USA. Journal of Public Economics, 88, 1359-1386. https://doi.org/10.1016/S0047-2727(02)00168-8

Clark, A. E. (2005). What Makes a Good Job? Evidence from OECD Countries. In S. Bazen, C. Lucifora, \& W. Salverda (Eds.), Job Quality and Employer Behaviour (pp. 11-30). London: Palgrave Macmillan. https://doi.org/10.1057/9780230378643_2

Clark, A. E. (2015). What Makes a Good Job? Job Quality and Job Satisfaction. IZA World of Labor No. 215. https://doi.org/10.15185/izawol.215

Cling, J. P., Razafindrakoto, M., \& Roubaud, F. (2012). To Be or Not to Be Registered? Explanatory Factors behind Formalizing Non-Farm Household Businesses in Vietnam. Journal of the Asia Pacific Economy, 17, 632-652. https://doi.org/10.1080/13547860.2012.724553

Comini, G., \& Teodosio, A. (2010). The Promises of Inclusive Business for the Poverty: Lessons from the Brazilian Context.

D’Addio, A. C., Eriksson, T., \& Frijters, P. (2007). An Analysis of the Determinants of Job Satisfaction When Individuals' Baseline Satisfaction Levels May Differ. Applied Economics, 39, 2413-2423. https://doi.org/10.1080/00036840600707357 
Davoine, L. (2007). La qualité de l'emploi: Une perspective européenne. Doctoral Dissertation.

Falco, P., Kerr, A., Rankin, N., Sandefur, J., \& Teal, F. (2011). The Returns to Formality and Informality in Urban Africa. Labour Economics, 18, S23-S31. https://doi.org/10.1016/j.labeco.2011.09.002

Fougère, D. (2007). Les méthodes micro-économétriques d'évaluation, Banque de France, $N E R-2007, E$ \# 166.

Garcia-Serrano, C. (2008). Does Size Matter? The Influence of Firm Size on Working Conditions and Job Satisfaction (No. 2008-30). ISER Working Paper Series.

George, B., \& Khoja, F. (2012). Doing Good and Making Profits: A Case Study of Affordable Business Solutions. Review of Business, 32, 71.

Givord, P. (2015). Méthodes économétriques pour l'évaluation de politiques publiques. Economie \& Prévision, No. 1, 1-28. https://doi.org/10.3406/ecop.2014.8141

Hart, S. L., \& Milstein, M. B. (2003). Creating Sustainable Value. Academy of Management Perspectives, 17, 56-67. https://doi.org/10.5465/ame.2003.10025194

Harter, J., Hayes, T., \& Schmidt, F. (2002). Business-Unit-Level Relationship between Employee Satisfaction, Employee Engagement, and Business Outcomes: A Meta-Analysis. Journal of Applied Psychology, 87, 268-279. https://doi.org/10.1037/0021-9010.87.2.268

Idson, T. (1990). Firm Size, Job Satisfaction and the Structure of Work. Applied Economics, 22, 1007-1018. https://doi.org/10.1080/00036849000000130

ILO (2019). World Employment and Social Outlook: Trends 2019. Geneva: ILO.

Imbens, G. W., \& Wooldridge, J. M. (2009). Recent Developments in the Econometrics of Program Evaluation. Journal of Economic Literature, 47, 5-86.

https://doi.org/10.1257/jel.47.1.5

INSD (2016). Enquête Régionale Intégrée sur l'Emploi et le Secteur Informel. Rapport final, Institut National de la Statistique et de la Démographie.

Lecocq, A., Ammi, M., \& Bellarbre, E. (2014). Le score de propension: Un guide méthodologique pour les recherches expérimentales et quasi expérimentales en education. Mesure et Évaluation en Éducation, 37, 69-100. https://doi.org/10.7202/1035914ar

Liloko, E., \& Kini, J. (2017). Inclusive Business-A Business Approach to Development. Current Opinion in Environmental Sustainability, 24, 84-88. https://doi.org/10.1016/j.cosust.2017.03.001

Lisi, G. (2018). Job Satisfaction, Job Match Quality and Labour Supply Decisions. International Review of Economics, 65, 489-505. https://doi.org/10.1007/s12232-018-0311-1

London, T., \& Hart, S. L. (2010). Next Generation Business Strategies for the Base of the Pyramid: New Approaches for Building Mutual Value. Delhi: Pearson Education India.

Michelini, L. (2012). Corporate Social Entrepreneurship and New Business Models. In Social Innovation and New Business Models (pp. 19-35). Berlin: Springer. https://doi.org/10.1007/978-3-642-32150-4_2

Mincer, J. (1974). Schooling, Experience, and Earnings. New York: Columbia University Press.

Naguib, R., \& Jamali, J. (2015). Female Entrepreneurship in the UAE: A Multi-Level Integrative Lens. Gender in Management: An International Journal, 30, 135-161. https://doi.org/10.1108/GM-12-2013-0142

Prahalad, K., \& Ramaswamy, V. (2004). Co-Creation Experiences: The Next Practice in Value Creation. Journal of Interactive Marketing, 18, 5-14. 
https://doi.org/10.1002/dir.20015

Rakotomanana, F. (2011). Les travailleurs du secteur informel sont-ils les plus heureux? Le cas de l'agglomération d'Antananarivo. Secteur informel urbain, marché du travail et pauvreté. Essais d'analyse sur le cas de Madagascar.

Razafindrakoto, M., \& Roubaud, F. (2006). The Determinants of Subjective Poverty: A Comparative Analysis between Madagascar and Peru. Document de Travail DIAL. Paris: Développement Institutions et Analyses de Long Terme. http://www.dial.prd.fr/dial_publications/PDF/Doc_travail/2006-01_english.pdf

Robins, J., Sued, M., Lei-Gomez, Q., \& Rotnitzky, A. (2007). Comment: Performance of Double-Robust Estimators When "Inverse Probability" Weights Are Highly Variable. Statistical Science, 22, 544-559. https://doi.org/10.1214/07-STS227D

Rosenbaum, P., \& Rubin, D. (1983). The Central Role of the Propensity Score in Observational Studies for Causal Effects. Biometrika, 70, 41-55. https://doi.org/10.1093/biomet/70.1.41

Schultz, T. W. (1981). Investing in People. The Economics of Population Quality. Los Angeles, CA: University of California Press. https://doi.org/10.1525/9780520318540

Sousa-Poza, A., \& Sousa-Poza, A. A. (2000). Well-Being at Work: A Cross-National Analysis of the Levels and Determinants of Job Satisfaction. The Journal of Socio-Economics, 29, 517-538. https://doi.org/10.1016/S1053-5357(00)00085-8

UN (2015). Millenium Development Goals: Report 2015.

Wooldridge, J. M. (2007). Inverse Probability Weighted Estimation for General Missing Data Problems. Journal of Econometrics, 141, 1281-1301.

https://doi.org/10.1016/j.jeconom.2007.02.002

Wossen, T. et al. (2017). Impacts of Extension Access and Cooperative Membership on Technology Adoption and Household Welfare. Journal of Rural Studies, 54, 223-233. https://doi.org/10.1016/j.jrurstud.2017.06.022 


\section{Appendix}

Table A1. Distribution of the number of employees matched by blocks.

\begin{tabular}{cccc}
\hline Lower boundary & \multicolumn{2}{c}{ BENEFICIARY } & Total \\
\hline 0.0899 & No & Yes & \\
0.2 & 195 & 41 & 236 \\
0.3 & 169 & 49 & 218 \\
0.4 & 122 & 72 & 194 \\
0.6 & 100 & 79 & 179 \\
0.8 & 24 & 53 & 77 \\
Total & 0 & 5 & 5 \\
\hline
\end{tabular}

Source: Authors from the survey data.

Table A2. Means or proportions for each indicator of job quality and differences tests (Non-Beneficiaries vs. Beneficiaries), Self-employed-Full data.

\begin{tabular}{|c|c|c|c|c|c|}
\hline \multirow{2}{*}{ Variable } & \multicolumn{2}{|c|}{ Non beneficiaries } & \multicolumn{2}{|c|}{ Beneficiaries } & \multirow{2}{*}{$\begin{array}{c}\text { Mean } \\
\text { /proportion } \\
\text { difference test }\end{array}$} \\
\hline & Obs & Mean/proportion & Obs & Mean/proportion & \\
\hline $\begin{array}{c}\text { Monthly } \\
\text { income (mean) }\end{array}$ & 754 & 228.05 & 392 & 413.18 & $\begin{array}{c}-185.13^{\star * *} \\
(-6.481)\end{array}$ \\
\hline $\begin{array}{l}\text { Working hours } \\
\text { per week (mean) }\end{array}$ & 754 & 45.98 & 392 & 40.22 & $\begin{array}{l}5.75^{\star * *} \\
(5.763)\end{array}$ \\
\hline $\begin{array}{l}\text { Looking for } \\
\text { a job (\%) }\end{array}$ & 754 & 48.40 & 392 & 36.98 & $\begin{array}{l}11.41^{\star * *} \\
(3.690)\end{array}$ \\
\hline $\begin{array}{c}\text { Satisfaction } \\
\text { with income (\%) }\end{array}$ & 754 & 50.26 & 392 & 65.56 & $\begin{array}{l}-15.29^{\star * *} \\
(-4.942)\end{array}$ \\
\hline $\begin{array}{c}\text { Satisfaction } \\
\text { with working } \\
\text { conditions (\%) }\end{array}$ & 754 & 59.01 & 392 & 74.48 & $\begin{array}{l}-15.47^{\star \star *} \\
(-5.186)\end{array}$ \\
\hline $\begin{array}{c}\text { Social } \\
\text { protection (\%) }\end{array}$ & 754 & 2.78 & 392 & 6.12 & $\begin{array}{l}-3.33^{\star *} \\
(-2.759)\end{array}$ \\
\hline
\end{tabular}

Source: authors' computation from the EMBEM database $(2015){ }^{* * *} p<0.01,{ }^{* *} p<0.05,{ }^{\star} p<0.1$.

Table A31. Means or proportions for each indicator of job quality and differences test (Non-Beneficiaries vs. Beneficiaries) for self-employed in Burkina Faso.

\begin{tabular}{cccccc}
\hline \multirow{2}{*}{ Variable } & \multicolumn{2}{c}{ Non beneficiaries } & Beneficiaries & $\begin{array}{c}\text { Mean } \\
\text { /proportion } \\
\text { difference }\end{array}$ \\
\cline { 2 - 5 } & Obs & Mean/proportion & Obs & Mean/proportion & $-168.92^{* * *}$ \\
$\begin{array}{c}\text { Monthly } \\
\text { income (mean) }\end{array}$ & 283 & 198.96 & 110 & 367.88 & $(-6.144)$ \\
$\begin{array}{c}\text { Working hours } \\
\text { per week (mean) }\end{array}$ & 283 & 48.66 & 110 & 44.52 & $4.15^{* *}$ \\
\hline
\end{tabular}




\section{Continued}

\begin{tabular}{cccccc}
\hline $\begin{array}{c}\text { Looking for } \\
\text { a job (\%) }\end{array}$ & 283 & 61.48 & 110 & 44.54 & $16.93^{* * *}$ \\
$\begin{array}{c}\text { Satisfaction } \\
\text { with income (\%) }\end{array}$ & 283 & 58.66 & 110 & 79.09 & $-20.43^{* * *}$ \\
$\begin{array}{c}\text { Satisfaction } \\
\text { with working } \\
\text { conditions (\%) }\end{array}$ & 283 & 63.60 & 110 & 75.45 & $(-3.797)$ \\
$\begin{array}{c}\text { Social } \\
\text { protection (\%) }\end{array}$ & 283 & 4.59 & 110 & 16.36 & $-11.85^{* *}$ \\
\hline
\end{tabular}

Note: values in parentheses are the t values. ${ }^{* *} p<0.01 ;{ }^{* *} p<0.05,{ }^{*} p<0.1$. The monthly income is in US dollars. Source: author's computation from the EMBEM database (2015).

Table A42. Means or proportions for each indicator of job quality and differences test (Non-Beneficiaries vs. Beneficiaries) for self-employed in Cote d'Ivoire.

\begin{tabular}{|c|c|c|c|c|c|}
\hline \multirow{2}{*}{ Variable } & \multicolumn{2}{|c|}{ Non beneficiaries } & \multicolumn{2}{|c|}{ Beneficiaries } & \multirow{2}{*}{$\begin{array}{c}\text { Mean } \\
\text { /proportion } \\
\text { difference }\end{array}$} \\
\hline & Obs & Mean/proportion & Obs & Mean/proportion & \\
\hline $\begin{array}{l}\text { Monthly income } \\
\text { (mean) }\end{array}$ & 471 & 245.53 & 282 & 430.85 & $\begin{array}{c}-185.2 \\
(-0.0078)\end{array}$ \\
\hline $\begin{array}{l}\text { Working hours per } \\
\text { week (mean) }\end{array}$ & 471 & 44.37 & 282 & 38.55 & $\begin{array}{l}5.82^{* * *} \\
(5.155)\end{array}$ \\
\hline $\begin{array}{l}\text { Looking for a job } \\
\text { (\%) }\end{array}$ & 471 & 40.55 & 282 & 34.04 & $\begin{array}{l}6.50^{\star} \\
(1.780)\end{array}$ \\
\hline $\begin{array}{l}\text { Satisfaction with } \\
\text { income (\%) }\end{array}$ & 471 & 45.22 & 282 & 60.28 & $\begin{array}{l}-15.06 \\
(-4.001)\end{array}$ \\
\hline $\begin{array}{c}\text { Satisfaction with } \\
\text { working conditions } \\
(\%)\end{array}$ & 471 & 56.26 & 282 & 74.11 & $\begin{array}{l}-17.85^{\star * *} \\
(-4.908)\end{array}$ \\
\hline $\begin{array}{l}\text { Social protection } \\
\text { (\%) }\end{array}$ & 471 & 1.69 & 282 & 2.12 & $\begin{array}{c}-0.43 \\
(-0.421)\end{array}$ \\
\hline
\end{tabular}

Source: author's computation from the EMBEM database (2015). The monthly income is in US dollars, ${ }^{* * *}$ $p<0.01 ;{ }^{* *} p<0.05,{ }^{*} p<0.1$

Table A5. Determinants of benefiting of an IB model for self-employed people.

\begin{tabular}{ccccccc}
\hline $\begin{array}{c}\text { Access to inclusive } \\
\text { business model }\end{array}$ & Total & $\begin{array}{c}\text { odds } \\
\text { ratio }\end{array}$ & $\begin{array}{c}\text { Cote } \\
\text { d'Ivoire }\end{array}$ & $\begin{array}{c}\text { odds } \\
\text { ratio }\end{array}$ & $\begin{array}{c}\text { Burkina } \\
\text { Faso }\end{array}$ & $\begin{array}{c}\text { odds } \\
\text { ratio }\end{array}$ \\
\cline { 2 - 7 } & & & & & & \\
\hline $\begin{array}{c}\text { sectors of activities } \\
\text { (ref: agriculture) }\end{array}$ & & & & & & \\
Fabrication & $-1.038^{* * *}$ & $0.354^{* * *}$ & $-2.353^{* * *}$ & $0.0951^{* * *}$ & $-0.624^{*}$ & $0.536^{*}$ \\
& $(0.272)$ & $(0.0963)$ & $(0.782)$ & $(0.0744)$ & $(0.326)$ & $(0.175)$ \\
Service/trade & $-0.294^{*}$ & $0.745^{*}$ & -0.334 & 0.716 & -0.399 & 0.671 \\
& $(0.173)$ & $(0.129)$ & $(0.223)$ & $(0.160)$ & $(0.302)$ & $(0.203)$ \\
\hline
\end{tabular}




\section{Continued}

\begin{tabular}{|c|c|c|c|c|c|c|}
\hline \multirow[t]{2}{*}{$\begin{array}{l}\text { Member of an association } \\
\quad(\text { Yes }=1, \text { No }=0)\end{array}$} & $0.395^{\star * *}$ & $1.484^{\star * *}$ & $0.557^{\star * *}$ & $1.746^{\star * *}$ & 0.167 & 1.182 \\
\hline & $(0.137)$ & $(0.203)$ & $(0.166)$ & $(0.290)$ & $(0.265)$ & $(0.314)$ \\
\hline \multirow{2}{*}{$\begin{array}{c}\text { Instruction } \\
(\text { Yes }=1, \mathrm{No}=0)\end{array}$} & -0.0769 & 0.926 & -0.0712 & 0.931 & -0.334 & 0.716 \\
\hline & $(0.193)$ & $(0.178)$ & $(0.222)$ & $(0.207)$ & $(0.423)$ & $(0.303)$ \\
\hline \multirow[t]{2}{*}{$\begin{array}{l}\text { Having a tax declaration of } \\
\text { existence }(\text { Yes }=1, \text { No }=0)\end{array}$} & $2.689^{* * *}$ & $14.71^{* * *}$ & $3.998^{* * *}$ & $54.47^{* * *}$ & $2.147^{* * *}$ & $8.560^{* * *}$ \\
\hline & $(0.307)$ & $(4.515)$ & $(0.771)$ & $(42.01)$ & $(0.439)$ & $(3.760)$ \\
\hline \multirow[t]{2}{*}{$\begin{array}{l}\text { Professional training } \\
\quad(\text { Yes }=1, \text { No }=0)\end{array}$} & 0.0317 & 1.032 & 0.0437 & 1.045 & 0.148 & 1.160 \\
\hline & $(0.190)$ & $(0.196)$ & $(0.223)$ & $(0.233)$ & $(0.382)$ & $(0.443)$ \\
\hline \multirow[t]{2}{*}{$\begin{array}{c}\text { Marital status } \\
(\text { Married }=1, \text { Single }=0)\end{array}$} & 0.104 & 1.109 & $0.867^{\star * *}$ & $2.380^{* * *}$ & $-0.570^{*}$ & $0.566^{\star}$ \\
\hline & $(0.200)$ & $(0.222)$ & $(0.290)$ & $(0.690)$ & $(0.299)$ & $(0.169)$ \\
\hline \multirow[t]{2}{*}{$\begin{array}{c}\text { Gender } \\
(\mathrm{M}=1, \mathrm{~F}=0)\end{array}$} & 0.0525 & 1.054 & $-0.358^{\star}$ & $0.699^{*}$ & $0.493^{*}$ & $1.638^{\star}$ \\
\hline & $(0.168)$ & $(0.177)$ & $(0.212)$ & $(0.148)$ & $(0.298)$ & $(0.488)$ \\
\hline \multirow[t]{2}{*}{ Age } & -0.000818 & 0.999 & 0.000204 & 1.000 & $-5.06 \mathrm{e}-05$ & 1.000 \\
\hline & $(0.00662)$ & $(0.00662)$ & $(0.00936)$ & $(0.00936)$ & $(0.00847)$ & $(0.00847)$ \\
\hline \multirow[t]{2}{*}{$\begin{array}{l}\text { Length of time } \\
\text { in the business }\end{array}$} & -0.00328 & 0.997 & 0.00858 & 1.009 & -0.0314 & 0.969 \\
\hline & $(0.00949)$ & $(0.00946)$ & $(0.0120)$ & $(0.0121)$ & $(0.0200)$ & $(0.0194)$ \\
\hline \multirow[t]{2}{*}{$\begin{array}{c}\text { Country } \\
(\mathrm{CIV}=0, \mathrm{BF}=1)\end{array}$} & 0.253 & 1.288 & & & & \\
\hline & $(0.171)$ & $(0.220)$ & & & & \\
\hline \multirow[t]{2}{*}{ Constant } & $-1.838^{* * *}$ & $0.159^{* * \star}$ & $-2.635^{\star * *}$ & $0.0717^{\star * *}$ & -0.662 & 0.516 \\
\hline & $(0.493)$ & $(0.0784)$ & $(0.604)$ & $(0.0433)$ & $(0.820)$ & $(0.423)$ \\
\hline Observations & 1,113 & 1,113 & 742 & 742 & 371 & 371 \\
\hline
\end{tabular}

Robust standard errors in parentheses, ${ }^{* *} p<0.01,{ }^{* *} p<0.05,{ }^{*} p<0.1$.

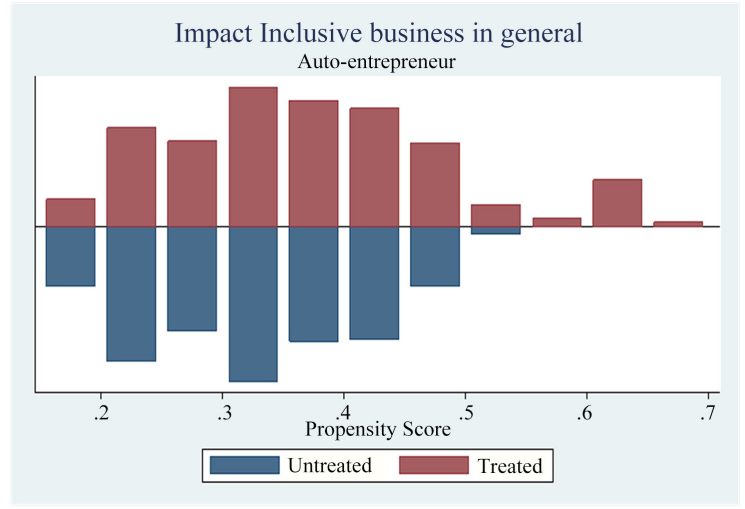



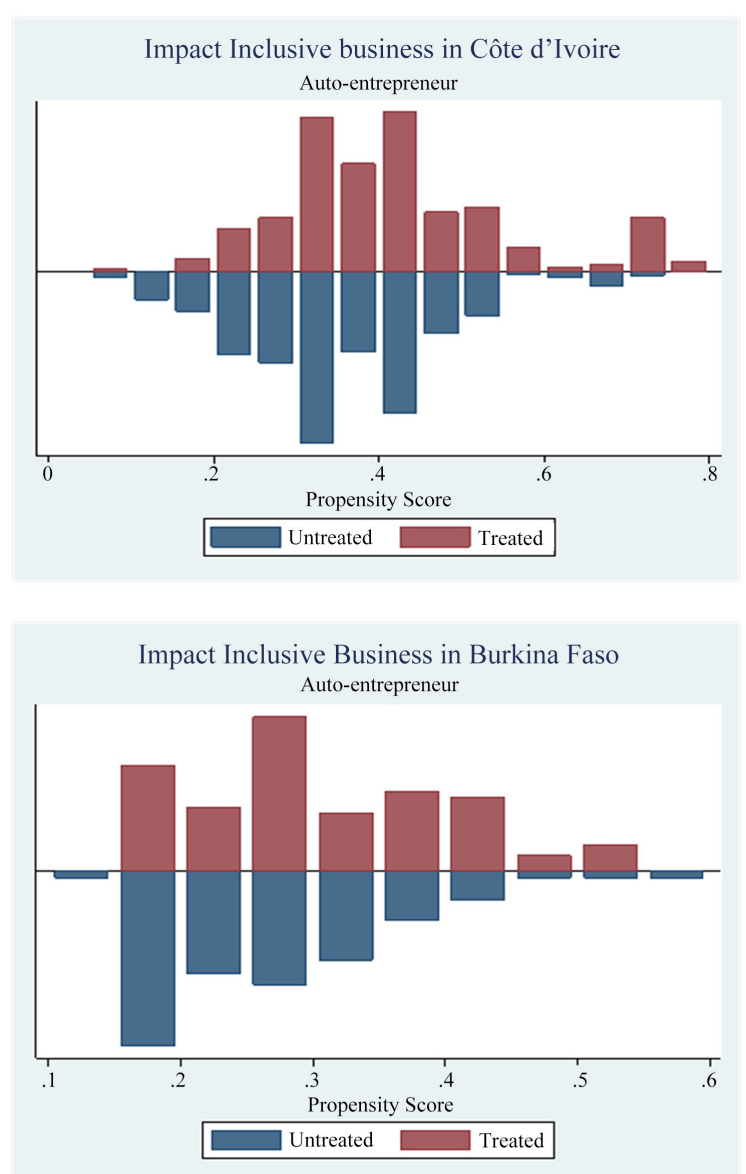

Figure 2. Common support region for beneficiary and non-beneficiary self-employed. Source: author's computation from the EMBEM database (2015). 